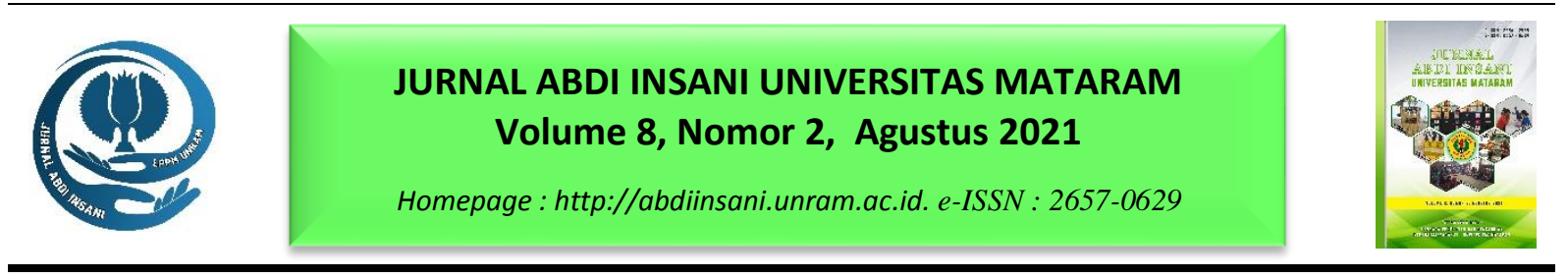

\title{
WORKSHOP PENULISAN PERSONAL STATEMENT DAN STUDY OBJECTIVE BAGI CALON PELAMAR BEASISWA PASCASARJANA
}

\section{Personal Statement And Study Objective Writing Workshop For Prospective Postgraduate Scholarship Applicants}

\author{
Dang Arif Hartono ${ }^{1 *}$, Stefanus Angga Badara Prima² \\ ${ }^{1}$ Program Studi Kewirausahan, Universitas Agung Podomoro, ${ }^{2}$ Program Studi Bisnis \\ Perhotelan, Universitas Agung Podomoro
}

APL Tower Lt.5, Jl. Letjen. S. Parman Kav. 28, Jakarta Barat, DKI Jakarta

Alamat korespondensi: dang.arif@podomorouniversity.ac.id

(Tanggal Submission: 1 July 2021, Tanggal Accepted : 19 Agustus 2021)

\begin{abstract}
Kata Kunci : Abstrak :
workshop, Seleksi beasiswa dan admisi ke program pascasarjana sangatlah kompetitif. personal Untuk dapat berhasil, peserta harus siap dengan beragam persyaratannya, statement, termasuk esai study objective dan personal statement. Tidak semua calon study pelamar beasiswa familiar dengan jenis esai ini, sehingga meneybabkan objective banyak peserta yang tereliminasi pada tahapan seleksi. Kegiatan pengabdian kepada masyarakat ini bertujuan untuk mempersiapkan calon pelamar beasiswa dari beragam kalangan dalam menulis kedua jenis esai tersebut. Kegiatan ini dilaksanakan dalam bentuk workshop secara daring dan peserta diminta untuk menuliskan esai personal statement dan study objective, yang kemudian direview dan diberikan sejumlah saran untuk meningkatkan kualitasnya. Hasil pelaksanaan workshop menunjukkan bahwa secara umum peserta sudah dapat menghasilkan esai yang fokus pada minat dan pengalaman riset, sehingga menonjolkan sisi kepakarannya. Evaluasi workshop menunjukkan bahwa materinya bermanfaat bagi peserta, dan umpan balik dari fasilitator dirasa sangat berguna untuk meningkatkan kualitas esai yang ditulis oleh peserta. Selain itu, peserta juga menyarankan agar diadakan workshop lanjutan yang membahas beragam tema terkait.
\end{abstract}

Panduan sitasi / Citation guidance (APPA $7^{\text {th }}$ edition) :

Hartono, D. A., \& Prima, S. A. B. (2021). Workshop Penulisan Personal Statement Dan Study Objective Bagi Calon Pelamar Beasiswa Pascasarjana. Abdi Insani, 8 (2), 158-167. http://doi.org/10.29303/abdiinsani.v8i2.404 


\section{PENDAHULUAN}

Saat ini melanjutkan pendidikan ke tingkat yang lebih tinggi sudah bukan lagi sebuah kemewahan milik kelas sosioekonomi atas saja. Ada banyak sekali beasiswa yang ditawarkan kepada khalayak umum, seperti beasiswa LPDP, Fulbright, Australia Awards, New Zealand ASEAN Scholarship, DAAD, dll. Masing-masing beasiswa tersebut memiliki persyaratan seleksi tersendiri. Meski begitu, diantara beragamnya persyaratan yang ditetapkan, terdapat sejumlah hal yang selalu diminta pada hampir semua beasiswa. Misalnya, sertifikat kemampuan berbahasa asing, esai personal statement dan esai study objective.

Banyaknya tawaran beasiswa membuat masyarakat berlomba-lomba mendaftar untuk mengikuti seleksi. Data LPDP (2015), memperlihatkan bahwa ada 38.790 orang pendaftar beasiswa LPDP pada tahun 2015. Secara akumulatif, dari tahun 2013 hingga 2015, total pendaftar beasiswa LPDP bahkan mencapai 100.550 orang LPDP (2015). Ini adalah jumlah yang sangat besar dan angka ini hanya memberikan gambaran tentang satu beasiswa saja, tidak mencakup jumlah aplikan beasiswa populer lainnya seperti Fulbright dan Australia Awards. Data tersebut memperlihatkan bahwa masyarakat Indonesia sudah memiliki minat yang tinggi untuk meningkatkan kapasitas diri dengan melanjutkan pendidikan ke jenjang pascasarjana.

Meski diikuti ribuan orang aplikan, hanya sedikit saja aplikan yang lolos seleksi dan memperoleh beasiswa. Dari 38.790 pendaftar beasiswa LPDP yang mengikuti seleksi di tahun 2015, hanya 4.651 peserta yang dinyatakan lolos dan mendapatkan beasiswa master dan doktoral, atau setara dengan 12\% dari total aplikan LPDP (2015). Beasiswa Fulbright bahkan lebih kompetitif lagi. AMINEF (2020), menyatakan bahwa peluang keberhasilan pendaftar beasiswa Fulbright hanya 6-8\% untuk jenjang master dan 5-8\% untuk jenjang doktoral.

Ada sejumlah faktor yang menyebabkan besar kecilnya peluang seseorang dalam seleksi beasiswa. Secara umum, faktor-faktor tersebut dapat dikelompokkan dalam dua kategori, yaitu faktor kebijakan dan faktor internal aplikan. Faktor kebijakan meliputi beragam kebijakan yang mempengaruhi tingkat keketatan seleksi dan ketersediaan kuota beasiswa setiap tahunnya. Hal ini dapat dipengaruhi banyak hal, seperti ketersediaan dana dari organisasi atau negara pemberi beasiswa, hubungan diplomatik antar negara, dll. Aspek-aspek ini dapat mempengaruhi jumlah anggaran dana atau kuota penerima beasiswa yang ditawarkan. Misalnya, sebelum tahun 2017, kuota penerima beasiswa Fulbright-Ristekdikti hanyalah 20 orang, namun sejak 2017 kuota tersebut ditingkatkan menjadi 50 orang (Astuti, 2017). Terakhir, pada tahun 2021, beasiswa FulbrightRistekdikti tidak menerima pendaftaran karena masih menunggu keputusan pendanaan dari Kemendikbud (AMINEF (2020). Contoh lainnya bisa dilihat pula pada perubahan kuota penerima beasiswa Stipendium Hungaricum. Awalnya, Stipendium Hungaricum menetapkan kuota 200 orang penerima beasiswa dari Indonesia, namun pada 2020 kuota ini dinaikkan menjadi 300 orang (Putra, 2020). Dari contoh-contoh tersebut, dapat disimpulkan bahwa faktor kebijakan merupakan hal yang tidak bisa diprediksi dan berada diluar kuasa aplikan beasiswa.

Faktor kedua adalah faktor internal aplikan. Faktor ini meliputi segala tindakan aplikan yang mempengaruhi kualitas aplikasi dan performanya dalam proses seleksi. Misalnya, kualitas esai personal statement dan study objective, kualitas proposal penelitian, tinggi atau rendahnya skor pada sertifikat kemampuan berbahasa asing, performa aplikan pada saat seleksi wawancara, dll. Faktor- 
faktor ini bersifat internal, yakni dominan bergantung pada upaya dan kapasitas aplikan beasiswa itu sendiri.

Diantara beragam faktor internal aplikan yang telah disebutkan sebelumnya, personal statement dan study objective memiliki peranan yang sangat penting. Brown (2004), bahkan menyatakan bahwa personal statement adalah komponen yang krusial karena memberikan kesempatan pada aplikan untuk memperlihatkan prestasi dan minat mereka guna memperkuat aplikasi pada program pendidikan masa depan mereka.

Ada sejumlah hal penting yang harus ditonjolkan dalam esai personal statement. Halberstam \& Redstone (2005), menemukan bahwa terdapat tiga aspek yang dilihat oleh penilai dari sebuah esai personal statement, yakni akurasi grammatikal, kualitas konten, dan komitmen aplikan terhadap disiplin ilmunya. Selain itu, Brown (2004), juga menemukan bahwa esai yang ditulis oleh aplikan yang sukses lebih banyak mengelaborasikan pengalaman riset dan minat riset bila dibandingkan dengan esai karya aplikan yang ditolak atau gagal. Senada dengan ini, Chiu (2015) juga menemukan bahwa sejumlah profesor dari universitas di Britania Raya dan Amerika Serikat menyukai esai yang memperlihatkan motivasi aplikan terhadap bidang studi yang akan dipelajarinya dan pengalaman serta latar belakang yang sesuai dengan minat riset mereka.

Selain hal-hal penting yang harus ditonjolkan, terdapat juga hal-hal yang harus dihindari. Ding, (2007) menemukan bahwa esai para aplikan yang gagal umunya banyak mengandung kisah pribadi yang tidak relevan dan tidak terkait dengan tujuan mereka untuk menempuh studi pascasarjana. Selain itu, Appleby \& Appleby, (2006) menyatakan bahwa damaging personal statement merupakan salah satu faktor utama yang menyebabkan aplikan program pascasarjana ditolak. Secara lebih lanjut Appleby \& Appleby, (2006) menjelaskan bahwa esai personal statement dianggap damaging bila mengandung sejumlah karakteristik, antara lain: 1) memperlihatkan isu personal mental health, 2) memperlihatkan excessive altruism, 3) memperlihatkan excessive self-disclosure, dan 4) bersifat professionally inappropriate. Memperlihatkan isu personal mental health contohnya ialah saat aplikan menceritakan bahwa ia memiliki isu kesehatan mental dalam esainya atau berargumentasi bahwa isu kesehatan mentalnya dapat diselesaikan dengan mengikuti kuliah pascasarjana. Excessive altruism, disisi lain, ialah memperlihatkan optimisme yang berlebihan bahwa seorang aplikan dapat membawa manfaat bagi orang banyak dengan mengikuti studi pascasarjana. Misalnya, dengan menuliskan "I want to help all people" atau "I am destined to save many people." Excessive self-disclosure dimaknai sebagai perilaku yang memberikan terlalu banyak informasi personal yang tidak relevan dengan tujuan belajar pada program pascasarjana yang dituju. Karakter professionally inappropriate dalam sebuah esai personal statement ini misalnya menceritakan hal-hal pribadi yang tidak relevan dengan perilaku professional yang diharapkan dan dilakukan oleh orang-orang dalam program pascarasajana atau bidang ilmu tertentu..

Selain keempat hal tersebut diatas, Appleby \& Appleby, (2006) juga menemukan bahwa bahwa kemampuan menulis yang buruk (poor writing skills) dapat membuat seorang aplikan ditolak. Kemampuan menulis yang buruk ini mencakup dua hal, yaitu spelling dan grammatical errors dan poorly written application materials.

Secara ringkas dapat disimpulkan bahwa esai personal statement dan study objective memiliki peran yang sangat penting. Tentunya bila esai personal statement yang buruk dapat membuat ditolaknya aplikasi seseorang pada sebuah program pascasarjana, maka secara logis hal yang sama tentu juga berlaku pada proses seleksi beasiswa. Menulis esai dengan dengan baik tentu akan 
membuat aplikasi beasiswa atau studi pascasarjana menjadi lebih kompetitif. Bercermin dari rendahnya persentase kelulusan seleksi beasiswa (hanya 5-12\%, sebagaimana dijelaskan sebelumnya), tidak berlebihan untuk menyimpulkan bahwa hal itu salah satunya disebakan oleh: 1 ) esai personal statement dan study objective yang ditulis oleh sebagian aplikan beasiswa dan studi pascasarjana kemungkinan mengandung konten yang bersifat damaging, dan 2) esai personal statement dan study objective yang ditulis oleh sebagian aplikan beasiswa dan studi pascasarjana kemungkinan memperlihatkan kemampuan menulis yang buruk (poor writing skills).

Meski sudah jelas betapa pentingnya peranan esai admisi (personal statement dan study objective), masih banyak calon aplikan beassiwa yang belum familiar atau mengetahui cara menulis esai ini. Swales (1996), menyatakan bahwa esai admisi seperti personal statement dan study objective merupakan tulisan yang masuk dalam genre "occluded" atau ragam tulisan yang tidak banyak diketahui orang. Maka dari itu, penulis melaksanakan Workshop Penulisan Personal Statement dan Study Objective sebagai bentuk kegiatan PKM (Pengabdian Kepada Masyarakat), yang bertujuan untuk: 1) memberikan pengetahuan tentang penulisan esai personal statement dan study objective yang baik, dan 2) membimbing peserta program untuk menghasilkan esai personal statement dan study objective yang baik, bebas dari konten yang bersifat damaging, serta tidak memperlihatkan poor writing skills.

\section{METODE KEGIATAN}

\section{Partisipan}

Peserta yang disasar dalam workshop ini adalah mereka yang ingin mengikuti seleksi beasiswa atau melanjutkan pendidikan ke jenjang pascasarjana di luar negeri. Pendaftaran dilaksanakan secara daring, dengan memposting dan menyebarkan poster workshop ke akun-akun tertentu yang memiliki banyak follower.

Pendaftaran dibuka selama satu minggu dan berhasil menjaring 35 orang pendaftar. Data dari formulir pendaftaran memperlihatkan bahwa 82,9\% pendaftar berniat melanjutkan studi ke jenjang doktoral dan $17,1 \%$ ingin melajutkan studi ke jenjang magister. Selain itu, mayoritas pendaftar (65,7\%) ingin mengikuti seleksi beasiswa LPDP, 51,5\% ingin mengikuti seleksi beasiswa Fulbright, dan sejumlah beasiswa lainnya. Sebanyak 12 orang pendaftar (34,3\%) telah memiliki kampus tujuan dan 23 orang $(65,7 \%)$ pendaftar lainnya belum menentukan pilihan universitas.

Meski demikian, pada hari pelaksanaan workshop, hanya 22 peserta yang dapat hadir mengikuti workshop. Peserta berasal dari beragam instansi di beragam wilayah Indonesia (Universitas Sanata Dharma, Universitas Indonesia, Universitas Gadjah Mada, Universitas Diponegoro, UIN Mataram, OJK, dII). Informasi detil mengenai peserta dapat dilihat pada Tabel 1. Untuk alasan kerahasiaan, semua nama peserta sudah diganti menggunakan pseudonym.

Tabel 1. Peserta Workshop Penulisan Personal Statement dan Study Objective

\begin{tabular}{llll}
\hline No. & Nama & Gender & Asal Institusi \\
\hline 1 & Peserta 01 & Wanita & Universitas Agung Podomoro \\
2 & Peserta 02 & Pria & Institut Pertanian Bogor \\
3 & Peserta 03 & Wanita & Universitas Gadjah Mada \\
4 & Peserta 04 & Pria & Universitas Aisyiyah Yogyakarta \\
5 & Peserta 05 & Wanita & Universitas Gadjah Mada
\end{tabular}




\begin{tabular}{llll}
6 & Peserta 06 & Pria & Universitas Diponegoro \\
7 & Peserta 07 & Wanita & Universitas Ma Chung \\
8 & Peserta 08 & Wanita & Universitas Gadjah Mada \\
9 & Peserta 09 & Pria & Universitas Terbuka \\
10 & Peserta 10 & Pria & Universitas Sarjanawiyata Tamansiswa \\
11 & Peserta 11 & Wanita & Universitas Indonesia \\
12 & Peserta 12 & Wanita & Wirausaha \\
13 & Peserta 13 & Pria & Yayasan Annaqiyah \\
14 & Peserta 14 & Wanita & Univeritas Negeri Padang \\
15 & Peserta 15 & Pria & IAIN Purwokerto \\
16 & Peserta 16 & Pria & 99.co \\
17 & Peserta 17 & Pria & RBC \\
18 & Peserta 18 & Wanita & Universitas Agung Podomoro \\
19 & Peserta 19 & Pria & Otoritas Jasa Keuangan RI \\
20 & Peserta 20 & Wanita & Universitas Swadaya Gunung Jati \\
21 & Peserta 21 & Wanita & Universitas Sanata Dharma \\
22 & Peserta 22 & Wanita & UIN Mataram \\
\hline
\end{tabular}

\section{Prosedur Pelaksanaan Kegiatan}

Karena masih dalam kondisi pandemi COVID-19, maka kegiatan dilangsungkan sepenuhnya secara daring. Urutan langkah pelaksanaan workshop ini dapat dilihat pada Tabel 2.

Tabel 2. Jadwal Pelaksanaan Kegiatan Workshop Penulisan Personal Statement dan Study Objective

\begin{tabular}{lc}
\hline \multicolumn{1}{c}{ Kegiatan } & Waktu \\
\hline Penyebaran informasi ke calon peserta & 22-29 Januari 2021 \\
Pelaksanaan workshop daring & 30 Januari 2021 \\
Penulisan esai personal statement dan study objective oleh peserta & 30 Januari - 2 Februari 2021 \\
Review esai dan pemberian feedback pada peserta & $2-8$ Februari 2021 \\
Evaluasi & 8 Februari 2021 \\
\hline
\end{tabular}

Adapun susunan acara pada hari pelaksaan workshop dapat dilihat pada Tabel 3 dibawah ini.

Tabel 3. Susunan Acara Workshop Penulisan Personal Statement dan Study Objective

\begin{tabular}{cl}
\hline Waktu & Mata Acara \\
\hline 09:00-09:10 WIB & Pembukaan \\
09:10-10:00 WIB & How to Write Your Study Objective \\
10:00-10:15 WIB & Sesi tanya jawab \\
10:15-11:45 WIB & How to Write Your Personal Statement Essay \\
11:45:12:00 WIB & Sesi tanya jawab \\
12:00-12:10 WIB & Penugasan dan penutupan \\
\hline
\end{tabular}




\section{HASIL DAN PEMBAHASAN}

Workshop dilaksanakan pada 30 Januari 2021, mulai pukul 09:00-12:00 WIB. Penulis memberikan pemaparan materi yang membahas pentingnya peran personal statement dan study objective serta bagian-bagian dan struktur kedua esai tersebut. Selain itu, peserta juga diajak untuk menganalisis beberapa contoh esai yang dianggap baik dan kurang baik, sehingga mereka bisa mengetahui apa saja yang harus dihindari saat nanti harus menuliskan esai mereka sendiri. Setelah itu, diadakan pula sesi tanya jawab untuk membantu peserta memahami materi yang disampaikan dengan lebih jelas.

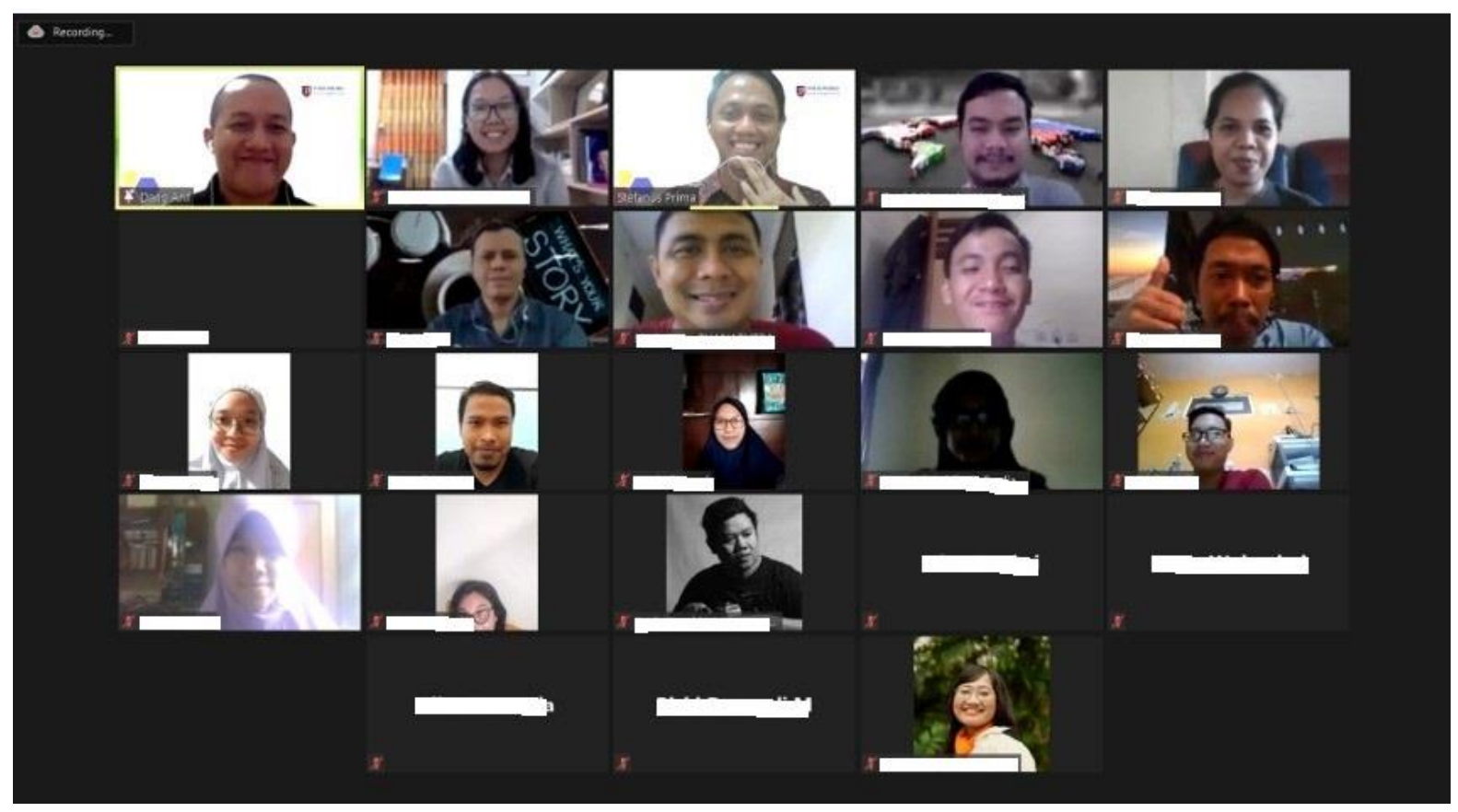

Gambar 1. Pelaksanaan Workshop secara Daring

Peserta kemudian diberi waktu selama 3 hari untuk menuliskan esai personal statement dan study objective masing-masing untuk kemudian mengirimkannya ke email penulis. Penulis lalu mereview semua esai yang diterima dan memberikan umpan balik untuk perbaikan kualitas esai peserta. Dua orang peserta diberikan sesi khusus untuk pemberian umpan balik melalui aplikasi Zoom karena dirasa sejumlah masukan bersifat sangat penting dan perlu disampaikan dengan mendetil secara lisan.

Dari hasil review yang dilakukan terhadap seluruh esai yang dikumpulkan, ditemukan bahwa mayoritas esai sudah mengandung komponen-komponen yang diharapkan. Semua esai telah memperlihatkan elaborasi detil mengenai pengalaman riset dan minat riset para calon aplikan, dan menonjolkan motivasi dan komitmen calon aplikan terhadap bidang studi atau disiplin ilmu yang ingin mereka pelajari. Selain itu, penulis juga tidak menemukan adanya konten yang bersifat damaging dari semua esai yang direview. Meski demikian, hampir semua esai masih memiliki permasalahan yang cukup serius dalam hal grammatikal, baik dalam struktur esai secara keseluruhan, maupun struktur kalimatnya.

Setelah semua peserta menerima umpan balik atas esai yang telah ditulisanya, maka workshop pun dinyatakan selesai dan peserta diminta untuk mengisi formulir evaluasi kegiatan workshop. 


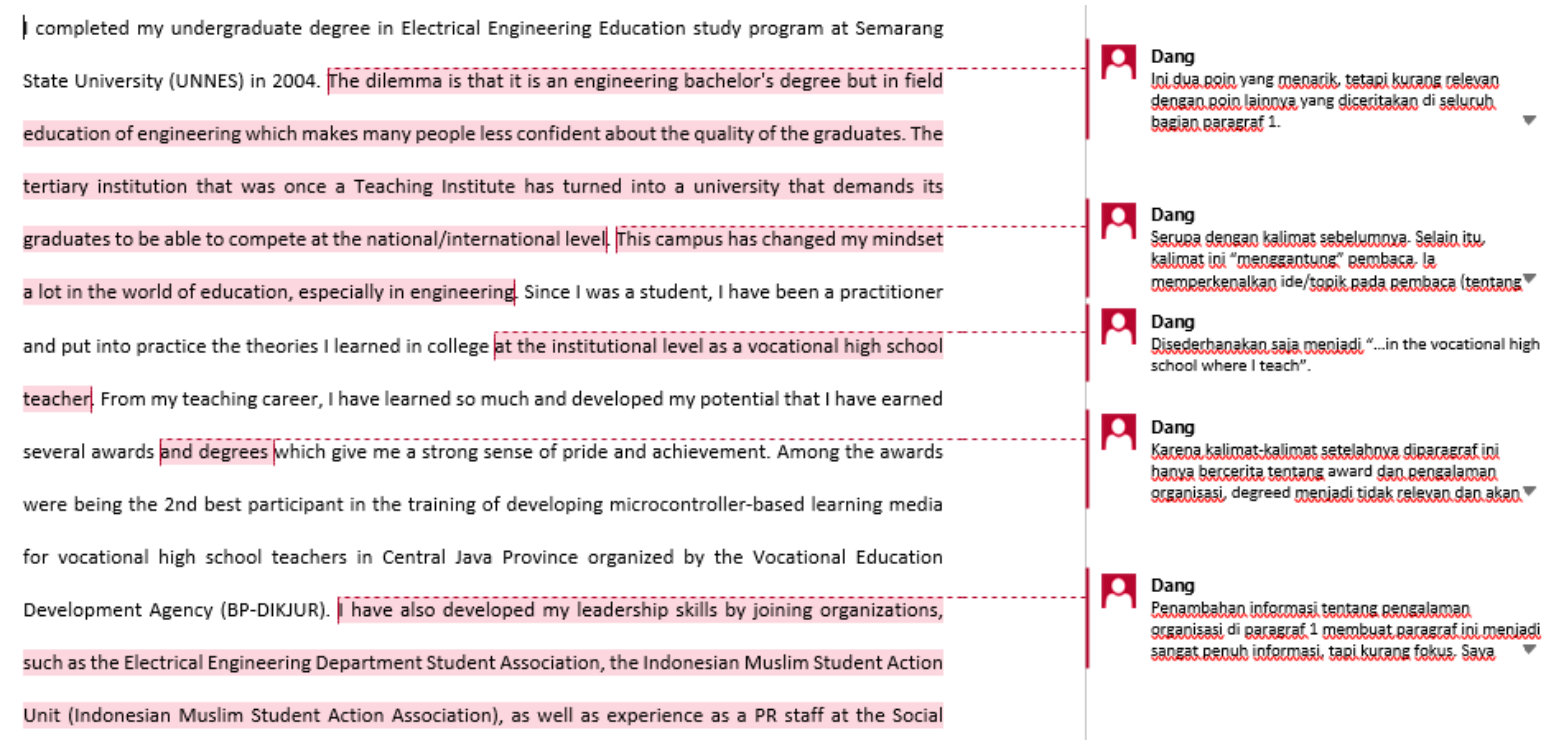

Gambar 2. Cuplikan Gambar Esai Peserta yang Diberikan Umpan Balik

Kualitas pelaksaanaan dan efektifitas workshop diukur menggunakan formulir evaluasi yang diberikan ke peserta melalui Google Form. Formulir ini mengandung 10 item pertanyaan: 6 pertanyaan dalam format skala Likert (skala 1 sampai 5, dimana angka 1 dimaknai 'Sangat tidak setuju' dan angka 5 dimaknai 'Sangat setuju') dan 4 pertanyaan terbuka. Tabel 3 memuat hasil pengukuran dari keenam item berbentuk skala Likert dalam formulir evaluasi.

Tabel 3. Hasil Evaluasi Pelaksanaan Workshop

\begin{tabular}{clc}
\hline No. & \multicolumn{1}{c}{ Pernyataan dan/atau pertanyaan } & Nilai rata-rata \\
\hline 1 & $\begin{array}{l}\text { Saya memahami materi tentang esai study objective yang } \\
\text { telah disampaikan }\end{array}$ & 4,9 \\
2 & $\begin{array}{l}\text { Saya memahami materi tentang esai personal statement yang } \\
\text { telah disampaikan }\end{array}$ & 4,8 \\
3 & $\begin{array}{l}\text { Materi yang disampaikan membantu saya dalam menulis esai } \\
\text { study objective }\end{array}$ & 5 \\
4 & $\begin{array}{l}\text { Materi yang disampaikan membantu saya dalam menulis esai } \\
\text { personal statement }\end{array}$ & 4,67 \\
& $\begin{array}{l}\text { Feedback yang diberikan fasilitator membantu saya dalam } \\
\text { meningkatkan kualitas esai study objective yang telah saya } \\
\text { tulis }\end{array}$ & 5 \\
& $\begin{array}{l}\text { Feedback yang diberikan fasilitator membantu saya dalam } \\
\text { meningkatkan kualitas esai personal statement yang telah } \\
\text { saya tulis }\end{array}$ & 5 \\
\hline
\end{tabular}

Temuan diatas menunjukkan bahwa secara umum penyampaian materi sudah sangat baik. Hal ini terlihat dari besaran nilai rata-rata yang diberikan oleh peserta $(4,9$ untuk pemahaman mereka terhadap materi penulisan esai study objective dan 4,8 untuk pemahaman mereka terhadap materi penulisan esai personal statement). 
Lebih lanjut lagi, dapat dikatakan bahwa materi yang telah disampaikan bermanfaat dan membantu para peserta workshop (nilai rata-rata 5 pada item 3, dan 4,67 pada item 4). Umpan balik yang diberikan pemateri dianggap peserta sangat membantu dalam meningkatkan kualitas esai yang mereka tulis (nilai rata-rata 5 baik untuk umpan balik pada esai study objective maupun esai personal statement). Tanggapan positif dari para peserta diperkuat juga oleh respon-respon peserta pada pertanyaan terbuka yang telah dirangkum pada Tabel 4.

Tabel 4. Rangkuman Respon Peserta pada Pertanyaan Terbuka dalam Formulir Evaluasi

\begin{tabular}{|c|c|c|}
\hline No. & Pertanyaan & Respon peserta \\
\hline 1 & $\begin{array}{l}\text { Hal apa yang } \\
\text { paling tidak anda } \\
\text { sukai dari } \\
\text { workshop ini? }\end{array}$ & $\begin{array}{l}\text { - Waktu terlalu singkat, padahal ada beberapa hal yang menurut saya butuh } \\
\text { penjelasan lebih lanjut tapi dijelaskan dengan buru-buru karena waktu } \\
\text { habis. } \\
\text { - } \quad \text { Tenggang waktu pengumpulan naskah tugas yang singkat } \\
\text { - Kurang global }\end{array}$ \\
\hline 2 & $\begin{array}{l}\text { Hal apa yang } \\
\text { paling anda sukai } \\
\text { dari workshop ini? }\end{array}$ & 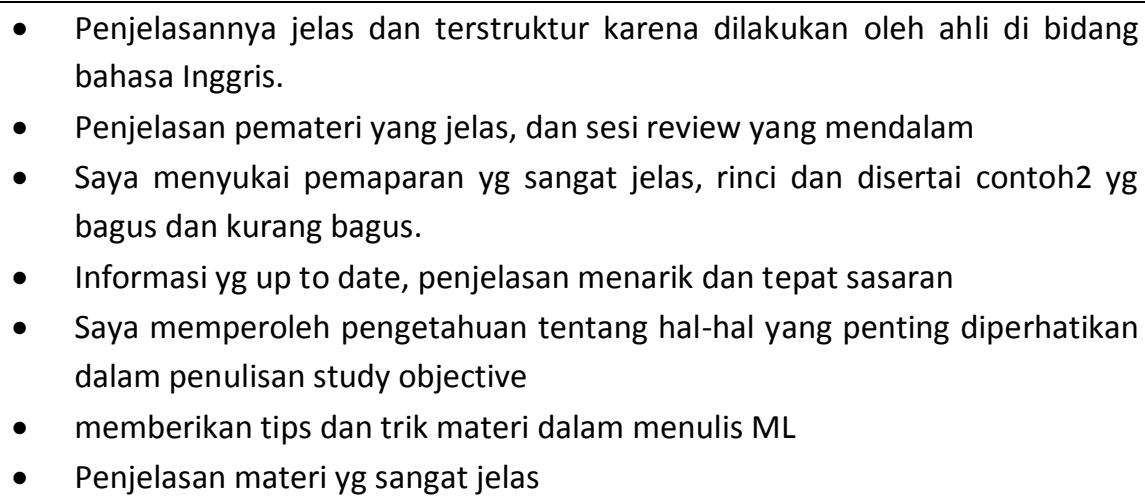 \\
\hline 3 & $\begin{array}{l}\text { Menurut anda, } \\
\text { bagaimana } \\
\text { sebaiknya } \\
\text { workshop ini } \\
\text { dilaksanakan? }\end{array}$ & $\begin{array}{l}\text { - Pelaksanaan secara umum sudah baik. Tapi jika boleh, sebaiknya ada } \\
\text { rekaman dan diunggah di Youtube atau website Podomoro University agar } \\
\text { yang tertinggal karena internet tidak stabil bisa melihat workshop secara } \\
\text { menyeluruh. } \\
\text { - Sudah terlaksana dengan baik, hanya saja utk submission mungkin agak } \\
\text { diperpanjang lagi. Saya sendiri tidak bisa mengumpulkan karena melewati } \\
\text { weekend adalah waktu untuk keluarga. Tidak bisa pegang laptop. Ketika } \\
\text { mendengarkan workshopnya pun saya struggling karena juga harus } \\
\text { mengurus anak. Atau mungkin sebaiknya dilaksanakan di weekdays. } \\
\text { Akan lebih baik apabila peserta diarahkan untuk membuat esai terlebih } \\
\text { dahulu sebelum workshop dilaksanakan } \\
\text { Alangkah lebih baik jangka waktu submissionnya sedikit di perpanjang }\end{array}$ \\
\hline 4 & $\begin{array}{l}\text { Menurut anda, } \\
\text { topik apa yang } \\
\text { layak atau penting } \\
\text { untuk dibahas } \\
\text { pada } \\
\text { seminar/workshop } \\
\text { di masa } \\
\text { mendatang? }\end{array}$ & $\begin{array}{l}\text { - Wawancara beasiswa } \\
\text { - } \quad \text { Tips interview Fulbright } \\
\text { - } \quad \text { Informasi mengenai adaptasi studi di LN, prospek kerja di LN atau dalam } \\
\text { - } \text { negeri } \\
\text { - } \quad \text { Tiat-kiat berkomunikasi dengan calon supervisor } \\
\text { - } \quad \text { Persiapan TOEFL atau IELTS tips dan triknya }\end{array}$ \\
\hline
\end{tabular}


Secara umum, kumpulan respon dari peserta workshop memperlihatkan bahwa workshop telah dilaksanakan dengan baik dan sangat bermanfaat bagi mereka. Meski demikian, terdapat beberapa catatan yang perlu dibahas demi perbaikan kualitas workshop dimasa mendatang. Pertama, terdapat seorang peserta yang menyatakan bahwa materi yang diberikan kurang global. Penulis menyelenggarakan workshop ini menjelang tenggat waktu pendaftaran beasiswa Fulbright (12 Februari 2021) dan kedua penulis merupakan alumni beasiswa Fulbright, sehingga penulis dengan sengaja menekankan bahwa banyak hal yang diajarkan dalam workshop berguna bagi para peserta yang hendak melamar beasiswa Fulbright. Meski demikian, penulis juga merasa perlu untuk menekankan bahwa esai personal statement dan study objective sering diminta sebagai persyaratan aplikasi beragam jenis beasiswa, sehingga materi yang disampaikan sebenarnya tetap relevan bagi peserta yang hendak melamar beasiswa selain Fulbright. Kedua, sejumlah peserta menyayangkan singkatnya waktu yang diberikan untuk menuliskan esai study objective dan personal statement. Waktu dua hari yang telah diberikan dirasa tidak cukup, mengingat mereka harus menggunakan waktu akhir pekan mereka untuk kegiatan keluarga, dll. Poin ini akan menjadi pertimbangan bagi penulis untuk melakukan perbaikan pada pelaksanaan workshop serupa dimasa mendatang.

Dari pertanyaan terakhir pada form evaluasi tersebut, penulis juga mendapatkan sejumlah masukan untuk melaksanakan tindak lanjut. Diantara masukan yang diberikan oleh peserta, penulis menganggap bahwa topik mengenai tips dan wawancara beasiswa serta persiapan TOEFL atau IELTS adalah topik yang layak untuk dijadikan workshop selanjutnya.

\section{KESIMPULAN DAN SARAN}

Secara umum, kegiatan ini dapat dikatakan cukup berhasil. Hasil yang diperoleh dari lembar evaluasi workshop memperlihatkan mayoritas peserta dapat memahami pemaparan tentang cara menulis esai personal statement dan study objective, dan pengetahuan yang mereka dapatkan sangat berguna untuk membantu mereka dalam menulis kedua jenis esai tersebut. Hasil review seluruh esai juga memperlihatkan bahwa mayoritas peserta sudah dapat menghasilkan esai personal statement dan study objective yang baik, menonjolkan aspek-aspek penting (elaborasi rinci mengenai pengalaman riset dan minat riset, dan menonjolkan motivasi dan komitmen terhadap bidang studi yang akan dipelajari), serta bebas dari konten yang bersifat damaging. Meski begitu, mayoritas peserta masih mengalami kesulitan untuk menulis esai yang bebas dari kesalahan gramatikal. Penulis merasa bahwa diperlukan waktu yang lebih lama untuk mengatasi permasalahan ini. Pelatihan lanjutan mungkn diperlukan untuk membantu peserta mengatasi kelemahan mereka dalam hal tersebut.

\section{UCAPAN TERIMA KASIH}

Penulis mengucapkan terima kasih kepada seluruh peserta yang terlah berpartisipasi pada workshop yang telah penulis selenggarakan. Selain itu, penulis juga berterima kasih kepada Universitas Agung Podomoro dan scholarly.id yang telah mendukung telaksananya kegiatan ini.

\section{DAFTAR PUSTAKA}

AMINEF. (2020). Frequently Asked Questions. American Indonesian Exchange Foundation. https://www.aminef.or.id/grants-for-indonesians/faq/

Appleby, D. C., \& Appleby, K. M. (2006). Kisses of Death in the Graduate School Application Process. 
Teaching of Psychology, 33(1), 19-24. https://doi.org/https://doi.org/10.1207/s15328023top3301_5

Astuti, K. (2017). Kuota Penerima Beasiswa Fullbright-Ristekdikti Naik. Republika. https://republika.co.id/berita/pendidikan/eduaction/17/05/31/oqs9bv428-kuota-penerimabeasiswa-fullbrightristekdikti-naik

Brown, R. M. (2004). Self-Composed: Rhetoric in Psychology Personal Statements. Written Communication, 21(3), 242-260. https://doi.org/https://doi.org/10.1177/0741088304264338

Chiu, Y. T. (2015). Personal statement in PhD applications: Gatekeepers' evaluative perspectives. Journal of English for Academic Purposes, 17(2), 63-73. https://doi.org/http://dx.doi.org/10.1016/j.jeap.2015.02.002

Ding, H. (2007). Genre analysis of personal statements: analysis of moves in application essays to medical and dental schools. English for Specific Purposes, 26(3), 368-392. https://doi.org/https://doi.org/10.1016/j.esp.2006.09.004

Halberstam, B., \& Redstone, F. (2005). The Predictive Value of Admissions Materials on Objective and Subjective Measures of Graduate School Performance in Speech-Language Pathology. Journal of Higher Education Policy and Management, 27(2), 261-272. https://doi.org/https://doi.org/10.1080/13600800500120183

LPDP. (2015). Improving, Upgrading, Uplifting, and Influencing: Laporan Tahunan 2015. Lembaga $\begin{array}{lllll}\text { Pengelola Dana } & \text { Pendidikan }\end{array}$ https://www.Ipdp.kemenkeu.go.id/api/Medias/a98129a9-c53a-4abc-bf38-359c25fb2a24

Putra, I. (2020). Hungaria Tambah 100 Kuota Beasiswa Kuliah untuk Indonesia. Medcom.ld. https://www.medcom.id/pendidikan/news-pendidikan/yNL4Eg2N-hungaria-tambah-100kuota-beasiswa-kuliah-untuk-indonesia

Swales, J. (1996). Occluded genres in the academy: the case of the submission letter. In E. Ventola, \& A. Mauranen (Eds.). Amsterdam: John Benjamins Publishing Co. 